\title{
The Effect of the Addition of "Senduduk" leaves (Melastoma malabthricum) on The Characteristic of Crackers
}

\author{
Kesuma Sayuti ${ }^{\text {** }}$, Deivy Andhika Permata ${ }^{\#}$, Oni Novita ${ }^{\#}$ \\ \# Department of Agricultural Product Technology, Andalas University, Limau Manis, Padang, Indonesia \\ E-mail: "kesuma@ae.unand.ac.id
}

\begin{abstract}
Many studies reported that "Senduduk" leaves have a bioactive component, but the utilization has not optimal. This study aimed to determine the effect of the addition of "Senduduk" leaves on the characteristics of crackers. This study used Completely Randomized Design (CRD) with 5 treatments, that was the addition of leaves $(\mathrm{A} ; 0 \%, \mathrm{~B} ; 4 \%, \mathrm{C} ; 6 \%, \mathrm{D} ; 8 \%$, and $\mathrm{E} ; 10 \%)$ and 3 replications. It was conducted in two stages. The first step was to determine the products that were well accepted (score $\geq 3.5$ ) by using sensory analysis. The second step was the chemical analysis of the products. The Data were analyzed using ANOVA and continued with Duncan New Multiple Range Test (DMNRT) at a significance level of 5\%. The results of the sensory analysis showed that all treatments were acceptable in color, crispness, and taste (score $\geq 3.5$ ). There are significant differences between the treatment on the moisture content, ash content, free fatty acid levels, and no significant difference between the treatment on the fat content and protein content. The best product was the addition of $8 \%$ leaves, with moisture content $3.84 \% \pm 0.57$; ash content $1.46 \% \pm 0.02$; fat content $21.86 \% \pm 0.43$; free fatty acids content $0.16 \% \pm 0.02$; protein content $8.93 \% \pm 0.48$; tannin $0.063 \% \pm 0.03$; quercitrin 2.74 $\mathrm{ppm}$, and antioxidant activity $\left(\mathrm{IC}_{50}\right) 7,013 \pm 124.56 \mathrm{ppm}$ and the mean value of sensory analysis were, $3.92 \pm 0.81$ of color, $4.24 \pm 0.66$ of crispness and $3.60 \pm 0.71$ of taste.
\end{abstract}

Keywords — antioxidant activity; crackers; quercitrin; “Senduduk” leaves; tannin.

\section{INTRODUCTION}

A"Senduduk" is a wild plant belonging to the Melastomataceae family. Usually, this plant grows in places that get enough sunlight. A part of the plant such as fruit, leaves, roots, and seeds, can be used as a treatment for various diseases [1]. Besides that, "Senduduk" fruit can be used as a natural coloring agent [2] The young "Senduduk" leaves are eaten as fresh vegetables for the treatment of rheumatism, arthritis and for relaxation of the feet[3]. It can also be used to treat digestive disorders (dyspepsia), bacillary dysentery, diarrhea, hepatitis, leucorrhoea, thrush, edema, and ulcers [1]. In the area of South Sulawesi, the local people use leaves and fruits as medicine to stomach aches, cough medicines, toothaches and wound medicine [4]. In West Sumatra, especially in the "Lubuak Tampuruang, Kuranji" area, young leaves are used as vegetables cooked with fish and are believed to be good for heart health.

Leaf extract produced using methanol as a solvent has the ability as an antimicrobial, but the extract produced using the water solvent does not show its activity as an antimicrobial [5]. "Senduduk" leaf extract (Melastoma malabathricum L.) contains active compounds that were alkaloids, saponins, tannins, phenolics, flavonoids, triterpenoids. steroids, and glycosides. The compounds that act as an antifungal. The fungus $T$. mentagrophytes is more sensitive to the inhibitory effect of "Senduduk" leaf extract, was compared with the yeast of Candida albicans [3].

One of the efforts to improve the utility "Senduduk" leaves is to produce functional food by using these leaves in the manufacture of snack products, one of them was crackers. Crackers are a type of biscuits or cookies which in its process, require fermentation or not, is flat, and when broken, the appearance looks multi-layered. It was hoped, the addition of "Senduduk" leaves resulting crackers that not only contain nutrients but also have functional added value [6]. The objective of this study was to study :(1), the effect of addition concentration of the leaves on the sensory analysis; (2) the characteristics of the crackers that acceptance by the panelists

\section{MATERIAL AND METHODS}

\section{A. Materials}

The main ingredient, in this study, "Senduduk" leaves (Melastoma malabathricum L.), was obtained from around of Limau Manis Campus of Andalas University Padang, Indonesia. The leaves were taken 1-3 of shoots. It also uses flour, margarine, salt, and water. Chemical material used was DPPH, (Aldrich), methanol, distilled water, quercitrum phosphoric acid (Merck), indigocarmin solution (Merck), 
$\mathrm{HgO}$ (Smart Lab), $\mathrm{HCl} 0.02 \mathrm{~N}$ (Smart Lab), $\mathrm{KMnO} 4$ $0.1 \mathrm{~N}$ (Merck), gelatin solution (Merck), ethanol 70\%, $\mathrm{H}_{2} \mathrm{SO} 4, \mathrm{~K}_{2} \mathrm{SO} 4$ (Merck), $\mathrm{NaOH}$ (Merck), hexane, petroleum ether (Merck), phenolftalein (Merck) and selenium mix (Merck).

\section{B. Experimental Design}

This study used Completely Randomize Design (CRD), 5 treatments and 3 replications; the treatments were the addition of "Senduduk" leaves as following

$$
\begin{aligned}
& A=0 \% \\
& B=4 \% \\
& C=6 \% \\
& D=8 \% \\
& E=10 \%
\end{aligned}
$$

Statistically, the analysis was used analysis of Variance and continued using Duncan's New Multiple Range Test (DNMRT) at a significant level of 5\%.

\section{Research Implementation}

1) Preparation of the Leaves: "Senduduk" Leaves obtained from around of Limau Manis Campus, was separated from the twig and dirt carried during harvest. The leaves were cleaned with running water then chopped using a knife.

2) Making of Crackers: Wheat flour of $300 \mathrm{~g}$ was mixed with "Senduduk" leaves, then added with water and stirring by hand until a smooth mixture form. Put the mixture in temperature room for \pm 15 minutes, so that it occurs fermentation naturally. Then the dough was printed and put in the oven at $175^{0} \mathrm{C}$ for 15 minutes.

3) The Observation: Moisture content [6], ash content, tannin content, quercitrin, and antioxidant activity were observed in the leaves of "Senduduk." Sensory analysis, moisture content [6], ash content, fat content, free fatty acid [6] and protein content [6] were observed in the cracker. On the best product was done an analysis of tannin, quercitrin (HPLC Method) and antioxidant activity $\left(\mathrm{IC}_{50} / \mathrm{HPLC}\right.$ Method)

\section{RESULTS AND DISCUSSION}

\section{A. Analysis of "Senduduk" Leaves}

Moisture content, ash content, tannin content, quercitrin, and antioxidant activity were observed in the leaves. Table I shows that the moisture content of the leaves was $78.17 \%$, the higher than the reported the other study [8] that was $70.40 \%$. It was assumed that these differences because of using the different position of the leaf. In our study using the young leaves.

The higher water in younger leaves is influenced by there are more active cells than older leaves so that more water is needed by young leaves. This condition causes the younger leaf has a relatively soft texture and relatively high humidity levels [9].

Ash content was $1.48 \%$, which is smaller than reported by the other study, which was $4.75 \%$ [8].
TABLE I

ANALYSIS OF "SENDUDUK” LEAVES

\begin{tabular}{|l|l|l|}
\hline No & Variable & Value \\
\hline 1 & Moisture content $(\%)$ & $78.17 \pm 1.607$ \\
\hline 2 & Ash content $(\%)$ & $1.48 \pm 0.008$ \\
\hline 3 & Tannin content $(\%)$ & $1.25 \pm 0.002$ \\
\hline 4 & Quercitrin $(\mathrm{ppm})$ & 48.22 \\
\hline 5 & Antioxidant activity $\left(\mathrm{IC}_{50} / \mathrm{ppm}\right)$ & $254.04 \pm 8.74$ \\
\hline
\end{tabular}

Ash content describes the mineral content in the food [10], it shows that ash content in our raw material was smaller than it was reported by other reported [8]. The ash content describes the metal ion in the food. The "Senduduk" flour contains Calcium and Phosphor [11].

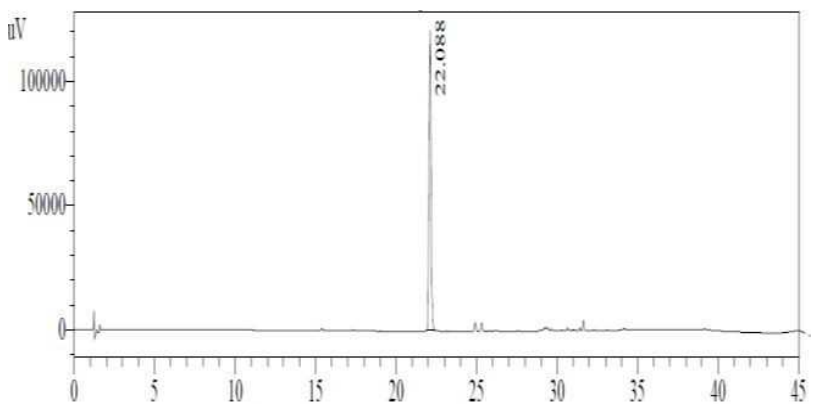

Fig. 1 The HPLC profile of quercitrin standard at wavelength $336 \mathrm{~nm}$

The tannin content in "Senduduk" leaves was $1.25 \%$, it was smaller than another researcher reported that was $3.53 \%$ [8]. In this our research, used younger leaves, but in the other research used old leaves [8]. A study had been conducted to show the chemical content of the "Rambutan" leaf on different position [12], it was reported that tannin in younger leaf smaller than the older leaf.

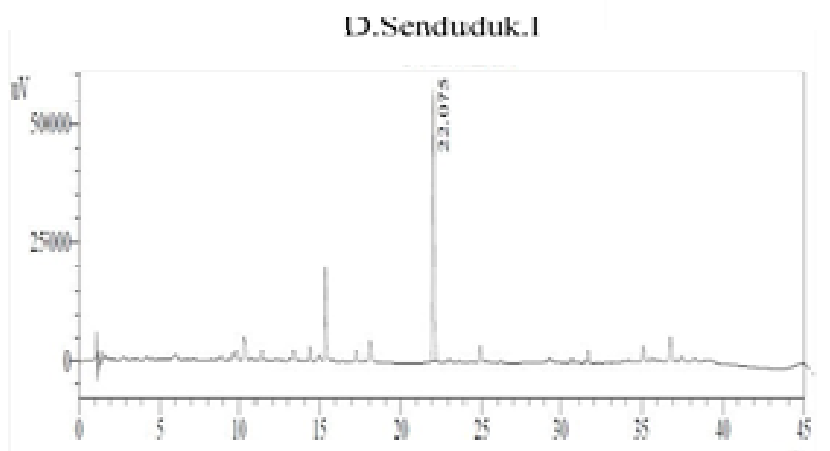

Fig. 2 The HPLC profile of "Senduduk" leaves at wavelength $366 \mathrm{~nm}$

Quercitrin in "Senduduk" leaf was $48.22 \mathrm{ppm}$. The retention time of the quercitrin standard is indicated by the appearance of peaks at a wavelength of $336 \mathrm{~nm}$. (figure 1) Based on the figure, the peak that appears is at the minute of 22.075. The appearance of a peak at the same wavelength and time as the quercitrin standard indicates the quercitrin content in the leaves of the" Senduduk." Flavonoid Quercetin is a major constituent of fruits and vegetables which naturally exists in the form of its glycosides, foremost as C3 glycosides. Three Quercetin glycosides namely quercitrin, quercetin 3- $\beta$-D-glucoside and quercetin 3-O-(6"O-malonyl)- $\beta$-D-glucoside[13]. In other researcher had been reported that the flavonoid in "Senduduk" leaves was quercitrin [14]. 
Table I shows that the value of $\mathrm{IC}_{50}$ was $254.04 \mathrm{ppm}$. This value can be interpreted that the ability of an antioxidant to capture $50 \%$ DPPH radicals is $254.04 \mathrm{ppm}$. It was indicated that antioxidant activity is moderate. A compound is said to be a very active antioxidant if the $\mathrm{IC}_{50}$ value is less than 50 $\mathrm{ppm}$, said to be active if a value of 50-100 ppm, said to be moderate if a value of 101-250 ppm, said to be weak if a value of $250-500 \mathrm{ppm}$, and said to be inactive if a value of more than 500 ppm.[15]

\section{B. Analysis of the Crackers}

1) Sensory characteristic: In general, determining the quality of foodstuffs is very dependent on several factors, including sensory characteristics and nutritional value [10]. One sensory characteristic was tested by using a hedonic rank test [16].

TABLE II

SENSORY CHARACTERISTIC OF CRACKERS

\begin{tabular}{|l|l|l|l|l|}
\hline No & $\begin{array}{l}\text { Addition of } \\
\text { 'Senduduk" } \\
\text { leaves }\end{array}$ & Color & Cripsness & Texture \\
\hline 1 & $0 \%$ & $3.72 \pm 0.98$ & $4.04 \pm 0.89$ & $3.56 \pm 0.77$ \\
\hline 2 & $4 \%$ & $3.80 \pm 0.76$ & $4.16 \pm 0.55$ & $3.52 \pm 0.92$ \\
\hline 3 & $6 \%$ & $3.92 \pm 0.57$ & $4.08 \pm 0.64$ & $3.56 \pm 0.92$ \\
\hline 4 & $8 \%$ & $3.92 \pm 0.81$ & $4.24 \pm 0.66$ & $3.60 \pm 0.71$ \\
\hline 5 & $10 \%$ & $3.52 \pm 0.87$ & $3.92 \pm 0.86$ & $3.48 \pm 0.96$ \\
\hline
\end{tabular}

Note: The value of hedonic ranking was $1-5 ; 1=$ dislike extremely, 2 = dislike, $3=$ rather like, $4=$ like dan $5=$ like extremely

There was not a significant difference between the treatments on the acceptance of color, crispness and the taste of the cracker $(\alpha>5 \%)$. Table II shows all products can be accepted by the panelist. The value was 3.52 - 3.92 for color, $3.92-4.24$ for crispness and $3.48-3.60$ for the taste. It was interesting that the crispness has higher value among the color and the taste. One of the characteristics of crackers is the crispness. Crispy crackers have a fragile texture when broken. The data shows that the adding of the "Senduduk" leaf has not significantly affected the color, crispness and the taste of the crackers.

\section{Chemical Characteristic of Crackers}

It was analyzed moisture content, ash content, protein content (Table III), fat content, and free fatty acid in the crackers (Table IV).

1) Moisture Content: The moisture content is one of the qualities of dry food products such as Crackers. Water can be an effect on the performance and taste of the food product[10]. The moisture content of the crackers was significantly different between the treatments $(\alpha \leq 5 \%)$. The higher the addition of the leaves, the higher the moisture content of crackers. It ranges from 2.43 in $0 \%$ leaves to 3.95 in $10 \%$ Leaves. The moisture content of all crackers still within the range of Indonesia Quality Standard (SNI) of Crackers. The maximal moisture content in crackers is $5 \%$ [6]. Increasing the leaves in crackers, the higher the moisture content of crackers. This is allegedly related to the nature of the leaves that contain lots of fiber that could bind water.
TABLE III

MOISTURE CONTENT, ASH CONTENT AND PROTEIN CONTENT OF THE CRACKERS

\begin{tabular}{|l|l|l|l|l|l|l|}
\hline No & $\begin{array}{l}\text { Addition of } \\
\text { “Senduduk" } \\
\text { leaves }\end{array}$ & $\begin{array}{l}\text { Moisture } \\
\text { content } \\
(\%)\end{array}$ & & $\begin{array}{l}\text { Ash content } \\
(\%)\end{array}$ & $\begin{array}{l}\text { Protein } \\
\text { content } \\
(\%)\end{array}$ \\
\hline 1 & $0 \%$ & $2.43 \pm 0.44$ & a & $0.83 \pm 0.29$ & a & $8.77 \pm 0.48$ \\
\hline 2 & $4 \%$ & $2.57 \pm 0.31$ & a & $1.13 \pm 0.29$ & ab & $8.39 \pm 0.67$ \\
\hline 3 & $6 \%$ & $2.83 \pm 0.39$ & a & $1.45 \pm 0.04$ & bc & $8.55 \pm 0.91$ \\
\hline 4 & $8 \%$ & $3.84 \pm 0.57$ & b & $1.46 \pm 0.02$ & bc & $8.93 \pm 0.48$ \\
\hline 5 & $10 \%$ & $3.95 \pm 0.48$ & b & $1.63 \pm 0.24$ & c & $8.44 \pm 0.24$ \\
\hline
\end{tabular}

Note: The number in the same column followed by unequal lowercase letter are significantly different at $\alpha=5 \%$ by Duncan's Multiple Range Test (DMNRT)

2) Ash Content: Ash is an organic material left over from burning food. Ash content and the composition depend on a variety of food and the way to burn. Most of the food ingredients, which is around $96 \%$ consist of organic matter and water. The rest is inorganic material in the form of minerals called ash [6]. Variance analysis of ash content in crackers showed that there is significantly difference between the treatment at a significance level of $5 \%$. The higher the addition of the leaves, the higher the ash content of crackers. Ash content ranges between 0.83 and $1.63 \%$.

3 ) Protein Content: Protein is an organic material that contains the amino acid, and it was related to a peptide bond. The atoms that make up the protein are consist of carbon, oxygen, nitrogen, and Sulphur [17]. By using variance analysis showed the addition of the leaves was not significantly difference in the protein content of the crackers at significance level $5 \%$. The protein content ranges between 8.44 and $8.77 \%$. Base on Indonesia National Standard (SNI biskuit 01-2973-2011), the protein content of crackers meets the standard, which was minimal of $5 \%$ [6].

TABLE IV

FAT CONTENT AND FREE FATTY ACID (FFA) IN CRACKERS

\begin{tabular}{|l|l|l|l|l|}
\hline No & $\begin{array}{l}\text { Addition of } \\
\text { "Senduduk" } \\
\text { leaves }\end{array}$ & $\begin{array}{l}\text { Fat Content } \\
(\boldsymbol{\%})\end{array}$ & FFA (\%) & \\
\hline 1 & $0 \%$ & $22.51 \pm 0.25$ & $0.11 \pm 0.03$ & $\mathrm{a}$ \\
\hline 2 & $4 \%$ & $22.73 \pm 1.04$ & $0.11 \pm 0.00$ & $\mathrm{a}$ \\
\hline 3 & $6 \%$ & $21.47 \pm 0.92$ & $0.12 \pm 0.02$ & $\mathrm{a}$ \\
\hline 4 & $8 \%$ & $21.86 \pm 0.43$ & $0.16 \pm 0.02$ & $\mathrm{~b}$ \\
\hline 5 & $10 \%$ & $22.03 \pm 0.22$ & $0.16 \pm 0.02$ & $\mathrm{~b}$ \\
\hline
\end{tabular}

4) Fat Content: Fat and lipid are the non-polar compounds which are insoluble in water produced by plants and animals [17]. Fats and oils have certain functions in food processing, such as contributing to the formation of texture and sensory quality of food products, heat transfer medium in the frying process, as well as solvents for fat-soluble essential vitamins (A, D, E, and K). Variance analysis shows that there is not significantly difference between the treatments on the fat content of crackers at significance level $5 \%$. The addition of the leaves has no affected on the fat content of the crackers. The fat content of crackers ranges from $21.47-22.51 \%$. The source of fat was margarine, which is added to all treatments in equal amounts, resulting in the same fat content in the product. "Senduduk" leaves contain low fat as reported by Dorisandi [11] "Senduduk" leaf flour contains crude fat content of $1.36 \%$. 
Free fatty acids found in fats or oils, one of which is oleic acid. Oleic acid is a free unsaturated fatty acid that is found in many triglycerides and has one double bond [11]. Variance analysis shows that the addition of the leaves has significantly affected on the FFA of the crackers at significance level 5\%. The range of the FFA was $0.11-$ $0.16 \%$. The higher the addition of the leaves, the higher the FFA of the crackers. It was in line with the moisture content of the crackers.

The higher the moisture content, the higher free fatty acid levels. free fatty acids are formed from hydrolyzed of triglycerides in fat molecules. Hydrolysis reactions can occur if there are water and heat. Indonesian national standard stipulates that free fatty acids for crackers should not exceed $1.0 \%$. Referring to the SNI standard, the levels of crackers free fatty acids in all treatments have met the SNI biscuit quality standard [11].

\section{The Best Product}

The best products are determined based on sensory characteristics and chemical characteristics. Based on these criteria, the best product is crackers with the addition of leaves with $8 \%$ (D treatment). The analysis carried out on the best product on the crackers included tannin levels, the antioxidant activity of quercitrin levels, in addition to proximate analysis and FFA levels.

TABLE V

TANNIN, QUERCITRIN DAN ANTIOXIDANT ACTIVITY IN THE BEST PRODUCT (ADDITION “SENDUDUK” LEAVES OF 8\%)

\begin{tabular}{|l|l|l|}
\hline No & Variable & Value \\
\hline 1 & Tannin $(\%)$ & $0.063 \pm 0.03$ \\
\hline 2 & Quercitrin $(\mathrm{ppm})$ & 2.74 \\
\hline 3 & Antioxidant activity $\left(\mathrm{IC}_{50} / \mathrm{ppm}\right)$ & $7,013.49 \pm 124.56$ \\
\hline
\end{tabular}

Tannin is a compound commonly found in leaves, stems, and fruit. Tannin compounds, including polyphenols, which have a sense of astringent [18] Table 4 shows that the tannin of crackers is $0.063 \%$. The tannin in the crackers comes from "Senduduk" leaves, which contains $1.25 \%$ of tannin. Tannin in the cracker decrease by $1.187 \%$ compared to in fresh leaves of "Senduduk." Tannins are polyphenols which are secondary metabolites in higher plants, which are galoil esters and their derivatives where the galoyl or their derivatives are attached to various polyols, catechins and triterpenoids (gallotannin, ellagitannin, and complex tannin), or they are all oligomeric and polymeric proanthocyanidins and polymers that can possess different interflavanyl coupling and substitution patterns (condensed tannins) [19]. Decreasing of tannin levels in the crackers is thought to be caused by several factors: (1), "Senduduk" leaves as a source of tannin only added as much as $8 \%$ to the mixture of raw materials; (2) the effect of heat. Making of cracker requires heat using an oven at $175 \mathrm{C}$ for 15 minutes. Research on oak seeds had been reported that a decrease in tannin levels from $11.69 \%$ in dry seeds to $8.55 \%$ in fried oak seeds at a temperature of $200{ }^{\circ} \mathrm{C}$ for 15 minutes [20].

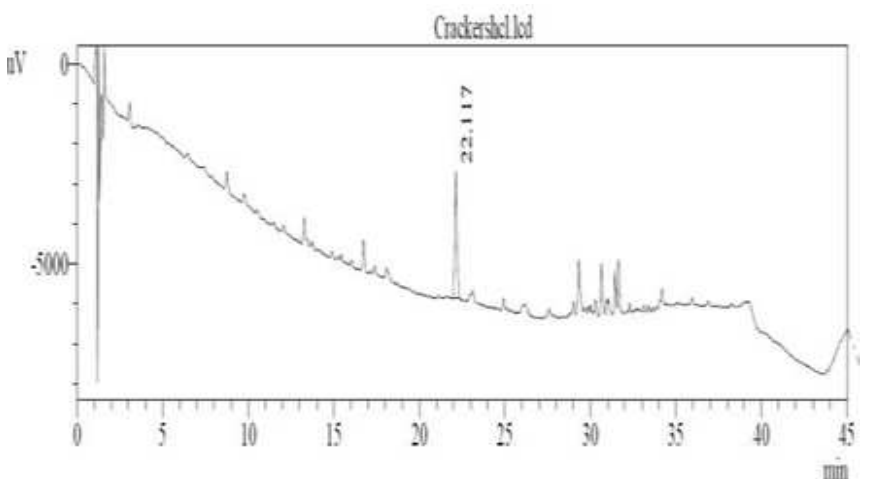

Fig. 3 HPLC profile of crackers with the addition of "Senduduk" leaves of $8 \%$

The presence of quercitrin compounds in crackers with the addition of leaves of $8 \%$ can be seen with the appearance of peaks at a wavelength of $336 \mathrm{~nm}$ and at the same minute as the quercitrin standard used (figure 3 ). Base on table V. Shows quercitrin in the crackers was $2.74 \mathrm{ppm}$. when compared to its contents in fresh leaves, it showed a large decrease, $48.22 \mathrm{ppm}$ in fresh leaves. It is assumed that there are two reasons; (1) Senduduk" leaves as a source of quercitrin only added as much as $8 \%$ to the mixture of raw materials; (2) the effect of heat. Making of cracker requires heat using an oven at $175 \mathrm{C}$ for 15 minutes.

Quercitrin is a type of antioxidant found in the leaves of "Senduduk" [15]. The decrease in quercitrin levels in crackers produced is in line with the decrease in the antioxidant activity value of the product.

Antioxidant compounds are compounds that can inhibit or slow down the damage caused by the oxidation process [21] Based on the antioxidant activity value of crackers using the $\mathrm{IC}_{50}$ method shows that, the ability of antioxidants in these products to capture free radicals by $50 \%$ is very weak $(>500$ ppm) [15]. Antioxidant activity in cracker has a large decrease when compared with antioxidant activity in the raw material of "Senduduk" leaves. This is thought to be caused by using leaves, which are only $8 \%$, and the use of high enough temperatures during the processing so that the antioxidant activity will be reduced.

\section{CONCLUSSION}

The addition of different concentrations of leaves had not significant effect on the color, crispness, and taste of crackers produced, and all products can be accepted by panelists with a score of $\geq 3.5$.

The addition of different concentrations of leaves had significantly affected the moisture content, ash content, and free fatty acid of the crackers, but there was not significantly different on fat content and protein content.

The best product was the addition of $8 \%$ leaves, with moisture content $3.84 \% \pm 0.57$; ash content $1.46 \% \pm 0.02$; fat content $21.86 \% \pm 0.43$; free fatty acids content $0.16 \% \pm$ 0.02 ; protein content $8.93 \% \pm 0.48$; tannin $0.063 \% \pm 0.03$; quercitrin $2.74 \mathrm{ppm}$, and antioxidant activity $\left(\mathrm{IC}_{50}\right) 7,013 \pm$ 124.56. 


\section{REFERENCES}

[1] S. Dalimartha, Atlas Tumbuhan Obat Indonesia, 11th ed. Jakarta: Trubus Agriwidya, 2008.

[2] K. Sayuti, R. Yenrina, and T. Anggraini, "Characteristics Kolang kaling (Sugar Palm Fruit Jam) with Added Natural Colorants,' Pakistan J. Nutr., vol. 16, no. 2, pp. 69-76, 2017.

[3] D. Gholib, "Uji Daya Hambat Daun Senggani (Melastoma malabathricum L.) Terhadap Trichophyton mentagrophytees DAN Candida albicans," Ber. Biol., vol. 9, no. 5, pp. 523-527, 2009.

[4] E. Tambaru, "Keragaman jenis tumbuhan obat indigenous di Sulawesi Selatan," J. Ilmu Alam dan Lingkung., vol. 8, no. 15, pp. 73, 2017.

[5] M. N. Diris, A. M. Basri, F. Metali, N. Ahmad, and H. Taha, "Phytochemicals and Antimicrobial Activities of Melastoma malabathricum and Melastoma beccarianum Leaf Crude Extracts," Res. J. Phytochem., vol. 11, no. 1, pp. 35-41, 2016.

[6] Standar Nasional Indonesia (SNI), SNI 2973-2011 Biskuit. Jakarta: Badan Standarisasi Nasional, 2011.

[7] K. Sayuti, D. A. Permata, and T. Anggraini, "Nutritional Value and Inhibitory Activity Alpha-Amylase of Cookies Made from Addition of Mulberry Leaf and the Extract," Pakistan J. Nutr., vol. 12, no. 8, pp. 775-781, Aug. 2013.

[8] C. . Lova, "Pembuatan Minuman Fungsional Teh Daun Senduduk (Melastoma malabathricum L.) Bercita Rasa Sari Buah Jeruk Nipis (Citrus aurantifolia)," Padang, 2014.

[9] A. Rauf, U. Pato, and D. F. Ayu, "Antioxidant Activity And Panelists Acceptance Of Avocado Leaves Tea Powder (Persea Americana Mill.) Based On The Leaf Position On The Branch," Jom FAPERTA, vol. 4, no. 2, 2017.

[10] F. . Winarno, Kimia Pangan dan Gizi. Jakarta: Gramedia Pustaka Utama, 2014

[11] M. Dorisandi, Y. Fenita, and E. Setrisno, "Pengaruhh Pemberian Tepung Daun Senduduk (Melasstoma Malabathricum L.) dalam Ransum terhadap Fraksi Lipid Darah dan Persentase Berat Organ dalam Ayam Beras," J. Sain Peternak. Indones., vol. 13, no. 4, pp. 325-336, 2018
[12] D. Andriyani, P. I. Utami, and B. A. Dhiani, "Penetapan Kadar Tanin Daun Rambutan (Nephelium Lappaceum.L ) Secara Spektrofotometri Ultraviolet Visibel," Pharmacy, vol. 07, no. 02, pp. 1-11, 2010.

[13] N. P. A, B. A. K, S. Bhattu, S. H. K, G. S. K, and S. G. S, "Antioxidant profiling of $\mathrm{C} 3$ quercetin glycosides: Quercitrin, Quercetin 3- $\beta$-D-glucoside and Quercetin 3-O-(6"-O-malonyl)- $\beta$ Dglucoside in cell free environment," Free Radicals Antioxidants, vol. 5, no. 2, pp. 90-100, 2015.

[14] S. S. Mamat et al., "Methanol extract of Melastoma malabathricum leaves exerted antioxidant and liver protective activity in rats," $B M C$ Complement. Altern. Med., vol. 13, no. 1, p. 326, Dec. 2013.

[15] M. Jun, H.-Y. Fu, J. Hong, X. Wan, C. S. Yang, and C.-T. Ho, "Comparison of Antioxidant Activities of Isoflavones from Kudzu Root (Pueraria lobata Ohwi)," J. Food Sci., vol. 68, no. 6, pp. $2117-$ 2122, 2003.

[16] C. Vindras and N. Sinoir, Technical Tasting Guide: Tools to integrate organoleptic quality criteria in breeding programs. Institut Tehnique de L' Agricultur Biologique.2017

[17] D. L. Nelson and M. M. Cox, Principles of Biochemistry, Fourth. Lehninger, 2010.

[18] N. Mutmainnah, S. Chadijah, and M. Qaddafi, "Penentuan Suhu Dan Waktu Optimum Penyeduhan Batang Teh Hijau (Camelia Sinensis L.) terhadap Kandungan Antioksidan Kafein, Tanin Dan Katekin," Lantanida J., vol. 6, no. 1, pp. 1-11, 2018.

[19] K. Khanbabaee and T. van Ree, "Tannins: Classification and definition," Nat. Prod. Rep., vol. 18, no. 6, pp. 641-649, 2001.

[20] S. Rakic, R. Maletic, M. Perunovic, and G. Svrzic, "Influence of thermal treatment on tannin content and antioxidation effect of oak acorn quercus cerris extract," J. Agric. Sci. Belgrade, vol. 49, no. 1, pp. 97-107, 2004.

[21] K. Sayuti and R. Yenrina, Antioksidan: Alami dan Sintetik. Padang: Unand Press, 2015. 